\title{
POTENSI BUdaYa masYaRAKat Bajo DI pulau bungIN kabupaten sumbaWa
}

\author{
THE CULTURAL POTENTIAL OF BAJO SOCIETY \\ IN THE ISLAND OF BUNGIN, DISTRICT OF SUMBAWA
}

\author{
Damardjati Kun Marjanto dan Syaifuddin \\ Puslitbang Kebudayaan, Kemdikbud \\ Pusat Bahasa Provinsi NTB \\ e-mail: damardjatikun@yahoo.co.id \\ e-mail: attuank@gmail.com
}

\begin{abstract}
Abstrak
Masyarakat Bajo di Pulau Bungin, Kabupaten Sumbawa, Provinsi Nusa Tenggara Barat, merupakan masyarakat laut yang berasal dari Sulawesi Selatan. Mereka bermigrasi sejak ratusan tahun yang lalu dan akhirnya menetap di kawasan pantai Pulau Sumbawa. Pada awalnya mereka tidak mendiami daratan seperti sekarang ini, melainkan hidup di laut sekitar pantai dengan sistem perumahan di atas air laut. Lama-kelamaan sebagai akibat adanya pertumbuhan penduduk, mereka mulai mengusahakan daratan dengan cara menimbun air laut dengan batu maupun karang yang sudah mati. Sebagai akibat dari pengaruh lingkungan, kebudayaan suku Bajo di Pulau Bungin saat ini mempunyai ciri khas kebudayaan dua lingkungan yaitu lingkungan laut dan daratan. Lingkungan yang dihadapi oleh masyarakat Bajo tersebut menghasilkan potensi, di mana potensi dimaknai sebagai kemampuan yang memungkinkan untuk dikembangkan. Potensi laut meliputi wilayah laut dan pantai yang kaya dengan sumberdaya alam, sedangkan wilayah daratan menjadi penting sebagai tempat tinggal dan wahana interaksi masyarakat. Potensi budaya di laut dan daratan yang meliputi sistem mata pencaharian tradisional, kesenian tradisional dan pengobatan tradisional tersebut apabila dapat dikelola dengan sebaik-baiknya, akan menjadi kekuatan bagi kemajuan masyarakat Bajo baik dalam bidang sosial maupun ekonomi. Dengan demikian penelitian ini penting dilakukan salah satu alasannya untuk menemukenali potensi budaya yang ada. Penelitian dilakukan dengan pendekatan kualitatif, adapun pengumpulan datanya dengan pengamatan dan wawancara.
\end{abstract}

Kata kunci: potensi budaya, masyarakat Bajo, Pulau Bungin.

\section{Abstract}

The Bajo people in Bungin Island, Sumbawa regency, West Nusa Tenggara Province, is a marine society from South Sulawesi. They migrated to the island hundreds of years ago and eventually settled in the coastal region of Sumbawa Island. At first they did not inhabit the land as it is today; instead they lived at the sea around the coast with on-the-sea-water housing system. Due to population growth over time, they began to seek more land by piling up the sea with rocks and dead coral. As a result of environmental influences, the Bajo of Bungin Island has currently two environmental cultural characteristics, both marine and terrestrial. These are potential environments to be developed. The sea around them is very rich in natural resources while the mainland is important as a place to live in as well as for community interaction. The cultural potential they have are, among others, traditional subsistence, traditional art, and traditional 
medicine. All of these have to be well-managed so that they can support the Baja people either socially and economically. This research conducted with a qualitative approach, the data obtained through observations and interviews.

Keywords: potential, culture, society.

\section{A. PENDAHULUAN}

Provinsi Nusa Tenggara Barat terdiri atas dua pulau, yaitu Pulau Lombok dan Pulau Sumbawa. Kedua pulau tersebut terbagi menjadi tujuh kabupaten dan dua kota. Pulau Lombok terdiri atas tiga kabupaten dan satu kota, yaitu Kabupaten Lombok Barat, Lombok Tengah, Lombok Timur, serta Kota Mataram. Sedangkan Pulau Sumbawa terdiri atas empat kabupaten dan satu kota, yaitu Kabupaten Sumbawa Barat, Sumbawa, Dompu, Bima, serta Kota Bima.

Sebagian besar kabupaten dan kota yang ada di provinsi ini ditemukan wilayah pemukiman etnis Bajo yang penduduknya hidup berkelompok (lihat Syarifuddin, 2008). Kabupaten yang dimaksud adalah Kabupaten Lombok Barat, Lombok Timur, Sumbawa Barat, Sumbawa, Dompu, dan Bima. Hal ini dapat dilihat pemukimanpemukimannya yang ada di daerah pantai pada wilayah kabupaten yang disebutkan di atas. Sebaliknya, tidak ditemukan kantong-kantong etnis Bajo yang mendiami wilayah Kabupaten Lombok Tengah. Lebih lanjut dideskripsikan oleh Syarifuddin ((2008: 102), bahwa wilayah etnis Bajo selalu berada pada pemukimanpemukiman pantai dan tidak ditemukan kantong-kantong etnis Bajo yang ada di pedalaman atau di tengah kota baik kota kabupaten maupun provinsi. Hal ini menandakan bahwa etnis Bajo belum dapat terlepas dari habitat aslinya yang dinamakan "laut". Hal ini disebabkan mata pencaharian utama mereka berhubungan dengan laut, yakni sebagai pencari ikan laut (nelayan).

Kantong-kantong yang dihuni oleh etnis Bajo yang ada di wilayah Kabupaten Sumbawa Barat adalah Desa Labuhan Lalar Kecamatan Taliwang dan Desa Labuhan Tano Kecamatan Seteluk.
Sementara itu, di wilayah Kabupaten Sumbawa, ditemukan etnis Bajo pada perairan Utara kabupaten tersebut khususnya pada Desa Labuhan Mapin Kecamatan Alas Barat, Pulau Bungin Kecamatan Alas, Pulau Kaung Kecamatan Buer, dan Desa Labuhan Bajo di Kecamatan Utan. Dalam tulisan ini, wilayah distribusi etnis Bajo tidak diamati pada semua kabupaten yang didiami etnis Bajo tersebut, namun hanya diambil daerah pengamatan yang ada di Kabupaten Sumbawa saja, khususnya yang tinggal di wilayah Pulau Bungin, Kecamatan Alas.

Pada saat kelompok manusia Bajo pertama berada di Pulau Bungin, hidup mereka benar-benar berada di pinggir laut terpisah dengan daratan. Namun seiring dengan perkembangan zaman dan meningkatnya populasi, lambat laun masyarakat Bajo mulai membiasakan diri menjadi manusia darat, terlebih lagi semenjak disatukannya Pulau Bungin dengan dataran Pulau Sumbawa. Semakin besarnya Pulau Bungin dan menjadi kawasan hunian masyarakat suku Bajo juga disebabkan adanya tradisi membuat daratan dengan cara menimbun laut di sekitar pulau mereka dengan batu sebagai tempat untuk membangun rumah bagi pengantin baru.

Meskipun masyarakat Bajo sudah bertempat tinggal dalam satu daratan dengan masyarakat lain, namun mereka memiliki tradisi dan kepercayaan yang berbeda dengan masyarakat Sumbawa pada umumnya. Tradisi laut yang sangat kental dari masyarakat Bajo Pulau Bungin, masih dipraktikkan oleh mereka, khususnya dalam kaitannya dengan mata pencaharian mereka sebagai nelayan. Demikian juga budaya yang mereka praktikkan saat ini juga menyesuaikan dengan kehidupan mereka yang sekarang, 
dimana daratan menjadi orientasi world view (pandangan dunia) yang berpengaruh terhadap budaya masyarakat, misalnya dalam hal rumah tinggal, kesenian, upacara adat, dan sebagainya.

Penelitian tentang Potensi Budaya Masyarakat Bajo di Pulau Bungin Kabupaten Sumbawa yang dilakukan pada tahun 2009 ini bertujuan untuk: pertama. menemukenali berbagai potensi budaya yang ada di masyarakat tersebut; kedua, untuk memahami potensi budaya sebagai salah satu kekuatan pendukung pengembangan sosial ekonomi masyarakat Bajo di Pulau Bungin; dan yang ketiga, sebagai bahan pembuatan kebijakan di bidang kebudayaan menyangkut pengembangan budaya lokal.

\section{B. METODE PENELITIAN}

Penelitian ini menggunakan pendekatan kualitatif dimana data diperoleh dengan cara observasi (pengamatan) serta wawancara dengan berbagai tokoh masyarakat Bajo yang ada di Pulau Bungin. Informan yang akan diwawancarai merupakan individu yang memahami betul budaya yang hendak diteliti dan mereka terlibat secara langsung dalam kebudayaan tersebut. Pemilihan informan juga dilakukan dengan teknik snowballing (bola salju), di mana satu informan merekomendasikan informan yang lain yang dianggap memiliki informasi yang sepadan atau lebih luas (Endraswara, 2003: 239). Data kualitatif yang berhasil dikumpulkan dari seluruh informan dikelompokkan sesuai dengan tema-tema yang ada dalam permasalahan penelitian. Setelah data dikelompokkan dalam satu tema, maka akan dicari hubungan antara satu data dengan data lainnya untuk memperoleh hasil sesuai dengan tujuan penelitian.

\section{HASIL DAN BAHASAN}

\section{Inventarisasi Data tentang Keadaan Sosio-Demografi, Kultural, dan Ekonomi}

Kecamatan Alas adalah salah satu kecamatan dari dua puluh kecamatan yang ada di Kabupaten Sumbawa. Kecamatan Alas terbagi menjadi delapan desa, yakni Desa Luar, Baru, Kalimango, Marente, Juran Alas, Alas Dalam, Labuhan Alas, dan Desa Pulau Bungin. Salah satu desa pada Kecamatan Alas yang dihuni oleh etnis Bajo adalah Desa Pulau Bungin. Pulau Bungin ini memiliki luas wilayah 9,00 hektar dengan jumlah penduduk 2995 jiwa yang terdiri dari 1436 laki-laki dan 1559 perempuan yang terbagi dalam 773 kepala keluarga (KK). Wilayah ini merupakan sebuah pulau yang dibangun sendiri oleh masyarakatnya. Jadi, dapat dikatakan bahwa desa ini tidak termasuk dalam katagori wilayah pedalaman.

Secara geografis, pulau ini berbatasan dengan beberapa wilayah, yakni (1) sebelah utara berbatasan dengan laut Labuhan Alas (Pulau Panjang); (2) sebelah selatan berbatasan dengan laut Desa Dalam; (3) sebelah barat berbatasan dengan laut Desa Gontar; dan (4) sebelah timur berbatasan dengan laut Pulau Kaung. Walaupun wilayah tempat tinggalnya berupa pulau kecil, namun pulau ini juga merupakan desa administratif, seperti desadesa lain yang ada di dataran Pulau Sumbawa. Pulau ini, mulanya bukan merupakan pulau yang telah ada di bagian utara Pulau Sumbawa, melainkan hanya sebuah tumpukan karang laut. Namun, lambat-laun anggota masyarakat yang ingin membuat rumah di pulau itu harus mengumpulkan batu karang sampai menutup air laut seluas rumah yang ingin dibangun. Sampai akhirnya, tempat ini menjadi sebuah pulau besar yang didiami oleh 2.995 jiwa. Berdasarkan pemaparan tersebut, otomatis mayoritas penduduk desa ini berprofesi sebagai nelayan karena di samping dihuni oleh orang Bajo yang dasarnya adalah orang laut yang mencari 
penghasilan di laut, juga letak geografis wilayah yang merupakan sebuah pulau yang dikelilingi oleh laut tersebut, walaupun saat ini sudah ada jalur yang menghubungkan daratan Sumbawa dengan Pulau Bungin.

\section{Mitologi Bajo di Pulau Bungin Sumbawa}

Masyarakat Bajo yang tersebar di beberapa wilayah di Sumbawa semuanya beragama Islam, termasuk orang Bajo yang tinggal di Pulau Bungin. Dalam menjalankan kehidupannya sehari-hari selalu berpedoman terhadap ajaran agama Islam yang di dalamnya termuat sabdasabda Tuhan yang mereka sebut dengan Papu (Allahtaalah). Oleh karena itu, sebagai pendukung aktivitas beragama, tersedia fasilitas ibadah yang beragam tingkatannya. Fasilitas yang dimaksud itu adalah langgar, musala, dan masjid. Fasilitas-fasilitas beribadah ini ditemukan pada setiap kantong wilayah pemukiman orang Bajo di Pulau Bungin Sumbawa.

Di samping mempunyai agama yang dianut, yaitu agama Islam, masyarakat Bajo di Pulau Bungin Sumbawa juga mengenal sistem mitologi. Mitologi yang dimaksud adalah ilmu tentang bentuk sastra yang mengandung konsepsi dan dongeng suci mengenai kehidupan dewa dan makhluk halus dalam suatu kebudayaan (KBBI, 2003). Mitologi dalam budaya Bajo di Pulau Bungin Sumbawa menyangkut (1) dunia gaib; (2) makhlukmakhluk halus; (3) kekuatan sakti; (4) kepercayaan mengenai penyakit; dan (5) kesusastraan suci (lihat Syarifuddin, 2010).

Dunia gaib. Orang Bajo di Pulau Sumbawa, termasuk Bajo Bungin menyadari bahwa dunia manusia terdiri dari dua aspek, yaitu dunia yang nyata dan dunia yang tidak tampak. Khusus dunia manusia yang tidak nyata inilah yang berhubungan dengan sistem kepercayaan. Dunia ini berada di luar jangkauan pancaindera manusia dan berada di luar batas akal pikirannya. Dunia inilah disebut dengan dunia gaib. Di dalam aspek dunia yang tidak tampak inilah diyakininya terdapat berbagai makhluk halus dan kekuatan sakti, yang tidak dapat dikuasai secara biasa, melainkan dengan cara luar biasa (lihat Danandjaja, 1980). Walaupun pada kenyataannya masyarakat Bajo mempunyai ilmu gaib secara kolektif untuk menghadapi makhluk-makhluk dan tenaga gaib tersebut, namun tidak menutup kemungkinan ketakutan juga sering muncul pada mereka. Oleh karena itu, jalan yang ditempuh yang paling wajar untuk menghadapi makhluk-makhluk gaib itu adalah mengambil hatinya dengan (i) menyapa dengan ilmu gaib pula yang berupa mantra dalam setiap akan melakukan kegiatan-kegiatan melaut mulai dari rumah sampai ke tengah laut dan (ii) mengadakan upacara-upacara persembahan (ritual) dengan memberikan apa yang disukai oleh makhluk-makhluk tersebut, seperti pesta pantai, tampoh tawar, dan upacara ritual lainnya baik yang dilakukan secara individu maupun secara kolektif. Kegiatan-kegiatan ini dilakukan agar makhluk-makhluk gaib tersebut menjadi senang atau menaruh belas kasihan kepada orang Bajo, sehingga tidak lagi mengusik kehidupan mereka, sebaliknya akan diberikan keselamatan dan sekaligus akan dimintakan rezeki yang melimpah kepada Wujud Tertinggi.

Makhluk-makhluk halus. Menurut masyarakat Bajo Pulau Bungin, makhlukmakhluk halus yang diyakininya mendiami dunia alam gaib yang ada di sekeliling kehidupan mereka itu ada yang berpenghuni di darat, darat-laut (pantai), dan ada juga di laut. Makhluk-makhluk halus yang dimaksud adalah (1) raja $a b u$ sebagai penghuni laut; (2) raja hundu adalah makhluk halus sebagai penghuni angin beliung; (3) nabi hilir adalah makhluk halus sebagai penjaga semua ikan di laut; (4) mboq karuku adalah makhluk halus sebagai penghuni laut dangkal di pinggir pantai; (5) mareba adalah makhluk halus sebagai penghuni pantai (darat-laut); (6) pengilir adalah makhluk halus sebagai 
penghuni daratan; dan (7) raja malela sebagai penghuni daratan luas termasuk gunung.

Raja abu adalah salah satu makhluk halus yang diyakini masyarakat Bajo di Sumbawa sebagai penguasa laut secara keseluruhan. Dengan demikian, penghuni laut ini diberikan sebutan sebagai raja laut, dan tempat tinggal raja abu ini sebagai istananya, yakni berada di tengah laut. Makhluk yang satu ini dikenal makhluk halus paling jahat di antara makhluk halus yang lainnya. Kejahatannya, makhluk halus ini akan mematikan setiap mangsanya dengan ciri-ciri badan yang kaku dan membiru. Munculnya raja abu di sekitar kehidupan orang Bajo di Pulau Bungin ditandai dengan datangnya arus kencang secara tiba-tiba dan tidak terarah serta apabila air laut berwarna gelap secara mendadak pula. Kehadiran raja abu ini sebagai akibat dari warga yang ingin memperkaya diri sendiri dan tidak ikhlas dalam memberikan sesuatu yang sudah semestinya milik raja abu. Untuk menyingkirkan makhlus halus ini, orang Bajo harus langsung menyebutkan namanya sebanyak tiga kali pada saat tanda-tanda kedatangannya itu mulai muncul.

Raja $a b u$ mempunyai saudara yang dikenal dengan nama raja hundu. Raja hundu adalah salah satu makhluk halus yang diyakini orang Bajo yang dapat berupa angin puting beliung. Raja hundu ini juga muncul pada saat angin datang baik berupa angin biasa sampai pada angin yang lebih kencang (badai atau topan). Raja hundu ini, apabila muncul akan menenggelamkan alat transportasi laut mulai dari sampan sampai kapal besar. Untuk menyingkirkan makhluk halus yang satu ini, orang Bajo yang ada di tengah laut harus menyebut namanya tiga kali.

Raja $a b u$ adalah penghuni laut, sedangkan yang melahirkan ikan-ikan di laut serta sebagai penjaga semua isinya dikenal dengan nama nabi hilir atau sebagian orang Bajo di Sumbawa mengistilahkan lain dengan nama nabi hidir. Nabi hilir atau hidir diyakini oleh mereka tidak sejahat raja abu. Makhluk halus ini hanya menampakkan diri dalam bentuk ikan yang besar. Oleh karena itu, untuk menyingkirkan makhluk halus ini, setiap mulai turun di awal musim, orang Bajo di Sumbawa diwajibkan mengadakan upacara ritual baik secara individu maupun kolektif. Akan tetapi, upacara itu selalu didahului dengan penyapaan kepada makhluk halus itu melalui mantra (1) pamuang kadi lau dan (2) pamunang $k a$ panjaga.

Mboq karuku adalah makhluk halus yang juga diyakini orang Bajo di Sumbawa sebagai penghuni laut dangkal di pinggir pantai. Makhluk halus yang satu ini sering menampakkan dirinya, sehingga tidak jarang orang Bajo dapat melihatnya. Orang Bajo yang sudah melihatnya menuturkan bahwa mboq karuku itu mempunyai rupa yang tinggi besar berkulit hitam legam dengan tidak mempunyai gigi sedikit pun. Mboq karuku ini, apabila muncul dapat mencelakai orang dalam bentuk kesurupan. Hal ini sering terjadi pada anak-anak yang sedang mandi di pinggir laut atau main di pinggir pantai. Dengan demikian, agar makhluk halus yang satu ini tidak mengganggu maka orang Bajo diwajibkan menyapanya dengan membaca mantra (1) gusoh dan (2) ninda boe yang diucapkan sebanyak tiga kali saat berada di pinggir pantai.

Makhluk halus lain yang diyakini orang Bajo selain yang disebutkan di atas adalah mareba sebagai penghuni pantai, yakni mulai pinggir pantai bagian darat sampai pinggir pantai bagian laut. Dengan kata lain, mareba ini sebagai penghuni tempat bertemunya antara darat dengan laut. Makhluk halus yang satu ini tidak mencelakakan orang dalam bentuk fisik, namun dapat merugikan orang dalam hal tidak mendapatkan rezeki saat melaut. Mareba ini, diyakini oleh orang Bajo sebagai pesuruh Tuhan, sehingga apabila mereka ingin meminta rezeki harus melalui perantara mareba dengan mengucapkan 
mantra ma seddi lepa pada saat berada di pinggir pantai.

Selanjutnya, makhluk halus yang diyakini orang Bajo di Pulau Bungin khusus sebagai penghuni di darat dapat dibagi menjadi dua penguasa, yaitu (i) pengilir sebagai penghuni daratan luas dan (ii) raja malela sebagai penghuni darat khusus gunung dan pulau yang ada di tengah laut. Kedua makhluk halus ini bertugas mencelakakan orang dengan berujung kematian. Pengilir ini berbadan tinggi besar, dia seperti raksasa dengan warna kulit hitam legam dengan gigi yang kemerah-merahan. Sebaliknya, raja malela mempunyai bulu seperti pisau belati di sekujur tubuhnya. Untuk menyingkirkan raja malela ini agar tidak mengganggu dan mencelakai orang maka harus disebut namanya sebanyak tiga kali saat berada di gunung atau pulau itu, sambil menyapanya dengan masing-masing mantra (1) bullu dan (2) pulo.

Kekuatan sakti. Masyarakat Bajo, seperti halnya etnis lain di Nusantara ini, juga percaya akan adanya kekuatankekuatan gaib dalam gejala-gejala, hal-hal, atau peristiwanya yang luar biasa. Gejalagejala dan hal-hal yang luar biasa itu dapat berupa gejala alam, tokoh-tokoh manusia, bagian-bagian tubuh manusia, binatang, tumbuh-tumbuhan, juga benda-benda dan suara-suara yang luar biasa. Sebaliknya, peristiwa-peristiwa luar biasa itu adalah peristiwa-peristiwa yang menyimpang dari kebiasaan jalan hidup manusia sehari-hari, atau peristiwa yang mengandung penuh bahaya bagi keselamatan hidupnya (Danandjaja, 1980: 335). Akan tetapi, khusus suara-suara yang luar biasa dan peristiwa-peristiwa yang dimaksud di atas, tidak diyakini oleh orang Bajo di Pulau Bungin.

Gejala alam yang dianggap orang Bajo di Pulau Bungin mempunyai tenaga gaib adalah angin yang bertiup dari arah barat daya, yaitu dari arah Gunung Rinjani di Pulau Lombok. Angin ini disebut dengan nama sangai timo. Apabila angin ini muncul maka bertanda dimulainya musim kemarau dan musim paceklik bagi nelayan Bajo di Sumbawa. Sangai timo ini akan mematikan tanaman di sawah dan mengusir ikan di laut. Angin ini bertiup sangat kencang dan menimbulkan gelombang yang besar pula sehingga para nelayan tidak berani turun melaut. Dengan angin ini juga, bagi semua yang berprofesi sebagai nelayan, susah mendapatkan ikan atau tidak seperti pada musim bara yang mudah dalam menangkap ikan yang banyak.

Tokoh-tokoh masyarakat yang dianggap mempunyai tenaga gaib adalah para sanro. Sanro ini mempunyai kemampuan gaib untuk menguasai atau mengendalikan tenaga alam, seperti hujan, angin, dan gelombang dan mencelakai orang dengan cara gaib, seperti membuat orang sakit bahkan mati, tidak bisa mendapatkan rezeki saat melaut, dan lainlain, serta dapat menyembuhkan penyakit hanya dengan membacakan mantramantranya. Adapun bagian tubuh manusia yang paling dianggap mempunyai kekuatan sakti, adalah pusar dan ubunubun. Pusar, menurut mereka adalah tempat terlahirnya manusia, sedangkan ubun-ubun adalah tempat keluar masuknya roh manusia. Oleh karena itu, para sanro yang ingin mengobati pasiennya, pasti dimulai dengan menyentuh pusar dan ubun-ubun, agar pasien yang diobati cepat sembuh.

Binatang yang dianggap mengandung kekuatan sakti adalah kucing untuk binatang yang ada di darat, sedangkan yang ada di laut adalah ikan paus dan duyung. Hampir semua rumah yang dihuni oleh orang Bajo di Pulau Bungin memiliki hewan peliharaan yang berupa kucing. Kucing, diyakini akan membawa berkah bagi pemeliharanya. Sebaliknya, apabila kucing itu mati karena terbunuh baik itu disengaja maupun tidak maka akan terjadi gejala alam berupa angin kencang dan gelombang besar serta tidak ada ikan yang naik sampai kurun waktu tertentu. Selanjutnya, ikan paus dan duyung, diyakini orang Bajo sebagai 
manusia juga, karena ikan paus bernafas dengan paru-paru, sama halnya juga dengan manusia, sedangkan ikan duyung mirip dengan manusia khsususnya wanita. Dengan demikian, kedua hewan laut itu tidak boleh ditangkap apalagi sampai dibunuh karena kedua hewan ini diyakini sebagai manusia juga yang dapat membantu para nelayan untuk mendapatkan rezeki dan keselamatan selama melaut.

Selanjutnya, benda-benda yang dianggap mempunyai kekuatan gaib bagi orang Bajo di Sumbawa adalah ulahu dan jima. Ulahu adalah salah satu benda yang diangap bertuah yang langsung diturunkan oleh Wujud Tertinggi dari langit, sedangkan jima adalah benda yang keramat yang dibuat oleh manusia yang sakti. Ulahu ini dapat berbentuk permata atau batu biasa, yang diyakini untuk kekebalan, mendapatkan rezeki banyak, dan kesehatan. Orang yang mendapatkan ulahu ini adalah orang yang beruntung karena sebelumnya diberikan arahan lewat mimpi oleh Wujud Tertinggi. Sebaliknya, jima dibuat untuk memperoleh kekebalan dan kekuatan fisik saja, seperti jima nambar.

Kesusastraan suci. Kesusastraan suci bagi orang Bajo di Sumbawa adalah cerita "Pitoto" si Muhamma" (lihat Ahimsa-Putra, 2001: 187-257). Cerita ini sangat melegenda di kalangan orang Bajo di Pulau Bungin sebagai sejarah kehidupan orang Bajo dalam pengembaraannya di laut. Selain cerita tersebut, orang Bajo juga mengenal mantra-mantra sebagai doa lisan suci. Mantra ini digunakan untuk menyapa Wujud Tertinggi dan alam sekitarnya agar mendapatkan apa yang diinginkannya, seperti perlindungan/keselamatan, rezeki melimpah, kesehatan, dan sebagainya.

\section{Ekologi Budaya Masyarakat Bajo di Pulau Bungin}

Masyarakat Bajo di Pulau Bungin Sumbawa bermatapencaharian sebagai nelayan. Oleh karena itu, masyarakatnya selalu menyesuaikan diri dengan suatu lingkungan geografi tempat hidup dan matapencahariannya tersebut. Lingkungan geografi yang dimaksud adalah laut. Pulau Bungin adalah sebuah pulau yang ada di wilayah tengah laut. Pada mulanya, pulau ini hanya dikelilingi laut (yang dalam bahasa Bajonya disebut dengan bungin) yang berbentuk bulan sabit (yang dalam bahasa Bajo disebut sekate), sehingga dinamakan bungin sekate. Lambat laun pulau ini berkembang menjadi desa administratif yang dikepalai oleh seorang kepala desa di dalam wilayah Kecamatan Alas dan nama desanya pun lebih dikenal dengan Pulau Bungin. Karena mereka hidup di laut maka pada awalnya mereka hanya menggunakan sistem teknologiteknologi yang berkenaan dengan laut (alat transportasi dan penangkapan laut) dalam sistem pengetahuannya. Di samping itu, khususnya alat transportasi laut digunakan juga dalam memperlancar kontak dengan pihak darat. Dengan perkembangan yang ada dan mereka merasa pentingnya melakukan hubungan dengan pihak luar maka mereka membuat jalan penghubung antara daratan dengan wilayah pulau. Oleh karena itu, masyarakat Bajo di Bungin tetap mempertahankan hubungan dengan lingkungannya sehingga dapat bertahan hidup. Hal inilah, merupakan salah satu sistem pengetahuan yang dimiliki masyarakatnya yang ada hubungannya dengan suatu bentuk teknologi yang digunakan dengan keadaan suatu lingkungan laut; pola-pola kelakuan dalam rangka mengeksploitasi suatu daerahnya yang erat kaitannya dengan bentuk teknologi yang diciptakan, seperti bentukbentuk alat transportasi laut, rumah pemukiman, alat-alat penangkapan ikan, dan sebagainya. Hal ini semakin unik bagi dunia orang Bajo di Pulau Bungin karena sistem mata pencaharian hidup dengan berbagai teknologinya, sistem kemasyarakatan, sistem religi yang dimiliki sekalipun tidak terlepas satu dengan yang lain merupakan 
perkembangan yang sejajar dari lingkungan-lingkungannya.

Lebih jelasnya dapat dilihat pada lingkungan orang Bajo Pulau Bungin tempat mencari sumber hayati laut, seperti lobster dan kerang mutiara; ada kecenderungan mereka mencari sumber hayati laut itu di lingkungan alam yang sulit karena didapatkan di wilayah laut daerah lain yang hidupnya berpencar. Pemencaran pencarian disebabkan di lingkungan laut sekitar wilayah pemukiman mereka sudah banyak lagi sumber hayati laut untuk ditangkap sebagai akibat dari jumlah penduduk masyarakatnya semakin banyak yang otomatis akan memperbanyak pula pelakupelaku pencarian hidup sebagai nelayan. Agar mereka mendapatkan hasil laut maka mereka harus benar-benar mengenal lingkungan tempat penangkapan hasil laut tersebut. Untuk itu, khusus dalam kegiatan ini, mereka secara berkelompok yang tergabung dalam sebuah perahu (bodi) yang isinya 10 sampai 15 orang dalam melakukan ekspedisi tersebut. Hal ini juga berlaku pada penggunaan jenis alat tangkap yang berupa serret yang memerlukan sistem kelompok penangkapan juga. Pemencaran di manamana, menimbulkan orang Bajo di temukan di berbagai wilayah perairan di Nusantara. Oleh karena itu, orang Bajo dikenal dengan istilah mencari kebajoaannya dalam hal ini hidup dalam pengembaraannya (lihat Ahimsa-Putra, 2001).

Sehubungan dengan itu, masyarakat Bajo di Pulau Bungin mempunyai sistem pengetahuan tentang ekosistem laut yang sangat mendalam, antara lain pengetahuan mengenai jam biologi ikan, yakni (i) waktu-waktu ikan mulai dan tidak makan, yaitu waktu dini hari sampai siang hari sekitar jam 11, (ii) waktu-waktu melaut yang disesuaikan dengan ada atau tidaknya cahaya bulan, apabila terang bulan maka ikan tidak dapat ditangkap dengan jaring, namun sebaliknya apabila bukan waktu terang bulan maka pada saat itulah ikan akan naik dan mudah ditangkap. Mengenai hal ini, dalam dunia orang Bajo dikenal dengan istilah wattu rendaman untuk saat tidak ada bulan dan tella bulang untuk saat terang bulan dan tidak ada ikan. Adanya kondisi bulan ini juga secara otomatis memengaruhi penanggalan naik atau surutnya air laut. Ini sangat penting bagi mereka karena berhubungan langsung dengan pemarkiran alat transportasi laut di wilayah pemukimannya. Di samping itu, juga untuk melihat kapan mereka harus turun ke laut dan kapan tidak karena pasang (dari barat daya ke timur) dan surutnya air laut (dari timur ke barat daya), akan memengaruhi arah arus yang ada di laut dan ini sekaligus memengaruhi makan atau tidaknya serta gerak perpindahan ikan di laut. Lebih jelasnya, jam biologi ikan dalam dunia orang Bajo di Pulau Bungin yaitu antara waktu magrib dengan waktu isha pada saat tella bulang, jam 3.00 pagi sampai 6.00 waktu fajar khusus untuk memancing malam. Untuk memancing pada siang hari mulai dari terbit matahari sampai jam 9.00 pagi atau dari jam 15.00 siang sampai waktu menjelang magrib. Kalau musim Barat yang sering muncul adalah arus pasang, sebaliknya musim kemarau itu adalah arus surut. Di samping itu, waktu untuk messi 'pancing' disesuaikan dengan adanya arus karena umpan pancing akan melayang atau berjoget-joget sehingga ikan akan mudah melihat dan kemudian memakannya. Dengan demikian dapat dikatakan, masyarakat Bajo di Pulau Bungin selalu memperhatikan lingkungan lautnya sehingga mereka mendapatkan hasil penangkapan yang banyak dan tidak sia-sia turun melaut.

\section{Potensi Sosial-Budaya yang Dapat Dikembangkan}

Terdapat semacam anggapan yang meluas bahwa tidak majunya masyarakat Bajo disebabkan oleh tidak adanya pemanfaatan potensi-potensi budaya yang dimiliki, sedangkan masyarakat Bajo 
mempunyai kekayaan budaya yang masih dipertahankan oleh generasi-generasinya. Ini semua terjadi terutama disebabkan oleh ketidaktepatan pendekatan pembangunan nelayan yang digunakan selama ini dan sebelumnya, khususnya ditujukan kepada masyarakat Bajo di Sumbawa. Mungkin karena ingin segera dapat menunjukkan kemajuan di bidang ekonomi masyarakat, pemerintah telah menempuh strategi pembangunan yang lebih menonjolkan pertumbuhan ekonomi, misalnya dengan pembukaan lahan-lahan tambak di areal tanaman bakau. Karena itu pula kontrol terhadap pengurasan dan pengrusakan sumberdaya alam dan lingkungan laut tempat mencari penghasilan hidup bagi nelayan menjadi sangat lemah, dan saat ini kondisi sumberdaya alam dan lingkungan laut sudah pada tingkat yang sangat mengkhawatirkan.

Kondisi ekonomi masyarakat Bajo sebagian besar warganya masih mengandalkan kegiatan sebagai nelayan, dewasa ini dapat dikatakan semakin menyedihkan. Hal ini disebabkan potensipotensi budaya mereka lambat laun semakin ditinggalkan. Karena, sistem teknologi penangkapan ikan mereka tidak memadai, walaupun ada beberapa sistem penangkapan itu merupakan alat strategis untuk meningkatkan kesejahteraan masyarakatnya secara umum, seperti alatalat yang diperlukan untuk kegiatan patuhung 'penyelaman' dan njareh 'menjaring'. Jika dari gambaran ini pemerintah tidak segera menindaklanjuti dengan langkah-langkah yang strategis dan terencana dengan baik, diperkirakan dalam jangka waktu satu atau dua dekade mendatang, keseluruhan perekonomian masyarakat nelayan khususnya masyarakat Bajo di perairan Nusantara ini yang masih intens mencari penghasilan hidup di laut, akan mengalami kemunduran yang semakin parah. Ada beberapa faktor yang dapat menjelaskan hal itu, antara lain wilayah laut tempat mencari penghasilan hidup yang semakin jauh karena lokasi penangkapan ikan di wilayahnya sudah tidak seperti dulu dengan jumlah hayati lautnya dan sistem terumbu karang, dan sebagainya. Hal ini dikarenakan (i) ekosistem laut di wilayahnya lambat laun sudah rusak oleh orang-orang yang menghalalkan segala cara untuk memperoleh ikan tanpa mengindahkan pelestarian ekosistem lautnya. Di samping itu, (ii) prasarana yang belum memadai dan kelembagaan ekonomi yang terbelakang, (iii) sumberdaya manusia yang tidak tergarap dengan baik, (iv) tata nilai yang belum sepenuhnya mencerminkan daya saing yang dapat diandalkan, dan (v) organisasi nelayan yang tidak berkembang sehat, yakni adanya persaingan antarwarga atau kelompok nelayan yang tidak sehat. Hal inilah yang merupakan permasalahan yang utama bagi masyarakat Bajo di Pulau Bungin yang harus diselesaikan agar pengembangan dan kesejahteraan masyarakatnya dapat tercapai. Di samping itu, adanya potensi-potensi budaya yang paling utama yang lain mendapatkan perhatian untuk dikembangkan (lihat unsur-unsur kebudayaan Bajo berikut). Oleh karena masyaraka Bajo di Pulau Bungin Sumbawa merupakan pelakupelaku bagi potensi-potensi budayanya, maka akan dilihat pada sistem teknologi, sistem pengetahuan, mata pencaharian, sistem religi, dan keseniannya, sedangkan bahasanya secara otomatis juga dijelaskan karena artefak-artefak kebudayaan dimunculkan melalui istilah-istilah bahasanya.

\section{a. Sistem Mata Pencaharian Tradisional}

Mata pencaharian masyarakat Bajo yang tingggal di Pulau Bungin Sumbawa adalah sebagai nelayan. Nelayan dalam konteks budaya mereka adalah kegiatan yang dilakukan untuk mendapatkan hasil fauna laut dengan cara messi 'memancing', njareh 'menjaring', patuhung 'menyelam', dan keramba 'budidaya ikan dan mutiara'. Dalam melakukan rutinitasnya sebagai nelayan itu tidak terlepas di sistem 
teknologi yang ada dalam dunianya, seperti alat transportasi laut dan alat penangkapan ikan. Oleh karena itu, dalam deskripsi ini juga sekaligus dijelaskan sistem teknologi nelayannya.

\section{1) Alat-alat Penangkapan Ikan}

Alat-alat penangkapan ikan ini disesuaikan dengan jenis kegiatan yang dilakukan.

\section{a) Messi 'memancing'}

Kegiatan messi 'memancing' dilakukan oleh setiap warga dengan menggunakan pessi 'alat pancing' untuk mendapatkan ikan. Ikan yang diperoleh dari jenis kegiatan ini hanya berupa jenis ikan sedang dan besar saja, sedangkan ikan kecil biasanya hanya digunakan sebagai umpan saja.

\section{b) Njareh 'menjaring'}

Kegiatan njareh 'menjaring' itu dilakukan dengan berbagai alat di antaranya adalah jareh, jareh tasi, jala, dari, serret, dan karakat. Jareh adalah jenis jaring yang terbuat dari tali nilon khusus jaring yang digunakan di laut yang dalam dan biasanya dipasang pada malam hari dengan menggunakan alat penerangan. Jareh ini mempunyai beberapa jenis, yaitu jareh sarrang 'jaring yang berukuran kecil', jareh tangnga 'jaring yang berukuran sedang', dan jareh buka 'jaring yang berkuran besar'. Khusus ketiga jenis jareh ini hanya digunakan dalam kegiatan ngoncor 'menjaring di waktu malam dengan menggunakan sampan' (lihat Syarifuddin, 2008).

Jareh tasi adalah jenis jaring yang terbuat dari tasi yang hanya digunakan pada siang hari pada laut dangkal. Jala adalah jenis jaring yang digunakan dengan cara dibuang pada saat melihat ikan khusus pada laut yang dangkal. Dari adalah jenis jaring yang digunakan oleh bagah 'perahu bagan' pada malam hari dengan bantuan alat penerangan. Dari ini berbeda dengan jareh yang disebutkan pertama di atas, jareh tidak dapat menangkap jenis ikan paling kecil, seperti ikan teri dan jenis- jenisnya, sedangkan dari dapat menangkap ikan mulai dari jenis ikan teri yang paling kecil sampai dengan ikan besar.

Serret adalah jenis jaring yang berukuran besar yang digunakan pada siang hari di wilayah tengah laut dan selalu menggunakan bido 'perahu'. Karakat adalah jenis jaring yang berukuran besar untuk menangkap ikan di pinggir laut. Jenis jaring terakhir ini, dalam penggunaannya, melibatkan banyak orang untuk memasang dan menariknya kembali. Biasanya bukan saja anak buah kapal (ABK) yang bekerja, namun dibantu oleh masyarakat yang ada di pinggir laut yang datang untuk macciro 'meminta ikan untuk dikonsumsi'.

\section{c) Matuhung 'menyelam'}

Jenis kegiatan lain dalam penangkapan jenis fauna laut adalah matuhung 'menyelam'. Kegiatan ini ada yang dilakukan untuk menangkap ikan dengan cara mana 'memanah' dan ada juga yang dilakukan untuk memasang $b u b u$ 'perangkap ikan'. Alatnya pun masingmasing dinamakan dengan pana 'panah' dan $b u b u$ 'perangkap ikan'.

\section{d) Keramba 'budidaya ikan'}

Di samping itu, ada kegiatan lain bagi sebagian kecil warga masyarakatnya, yaitu budidaya ikan batu karang, yang mereka sebut dengan keramba. Keramba ikan ini khususnya dibuat untuk membudidaya ikan kiapu 'kerapu', sunu 'sunu', langkoeh/lambe 'ikan napoleon'. Keramba ini berupa tong plastik dengan cara dibuat berbentuk rakit dengan jaring keliling di bawahnya. Hal ini dibuat agar ikan tidak keluar. Yang menjadi pelaku dalam aktivitas budidaya ini adalah orangorang tua (usia 40-55 tahun). Di Pulau Bungin terdapat 15 buah keramba dengan 15 orang sebagai pemilik. Keramba ini ditaruhkan pada kedalaman 10-15 meter. Bibitnya diambil oleh anak-anak yang khusus menangkap bibit ikan kerapu, namun kalau bibit budidaya ikan yang lain dibeli dari Pulau Bali dengan harga Rp 
7.000,- per ekor dengan panjang 6 sentimeter, sedangkan kerapu biasa seharga Rp 2.000,- per ekor. Budidaya ikan ini diambil hasilnya sekitar 1 tahun 1 kali untuk jenis ikan kiapu 'kerapu', bangeke 'sejenis ikan kakap' 10 bulan 1 kali panen, lambe 'langkoe' dalam 2 tahun 1 kali panen. Di antara jenis budidaya ikan tersebut, hanya ikan kerapu tikus dan langkoe dihargakan $\mathrm{Rp} 300.000,-$ an per kilo dengan keuntungan Rp 15.000.000,$(500 \mathrm{~kg})$.

Kegiatan paling utama dan sering dilakukan warga masyarakat Bajo di Pulau Bungin adalah ngoncor 'njareh' dan messi 'memancing'. Kedua kegiatan melaut ini khusus diperankan oleh orang tua Bajo yang ada di Pulau Bungin. Adapun jenis ikan yang paling banyak dihasilkan dengan kegiatan ngoncor adalah sibulah 'sarden', lure 'teri', ciro 'lemuru', sedangkan kegiatan messi khusus untuk menangkap jenis ikan besar. Kedua kegiatan ini dilakukan setiap hari dengan penyesuaian waktu-waktu melaut dan wilayah penangkapannya pun masih dalam sekitar wilayah pemukimannya, yakni di sepanjang perairan Pulau Panjang yang letaknya di bagian utara Pulau Bungin. Sebaliknya, apabila kegiatan menyelam dan menjaring dengan menggunakan serret itu sistemnya hanya sekali dalam setiap perjalanannya untuk pembagian pendapatannya. Hal ini sebagian besar diperankan oleh anak muda (remaja) karena kegiatan ini membutuhkan tenaga yang kuat dan waktu yang cukup lama. Oleh karena itu, dalam setiap perjalanannya, membutuhkan 10 sampai 14 orang berperan di dalam satu bido 'perahu'.

\section{2) Alat-alat Transportasi Laut}

Dalam melakukan aktivitasnya sebagai nelayan, di samping menggunakan alat-alat penangkapan ikan, ada juga yang paling penting adalah alat-alat transportasi lautnya. Alat-alat inilah yang akan membawa alat-alat penangkapan ikan serta mereka sebagai pelaku ke wilayah laut yang dituju untuk menangkap fauna laut yang diinginkan. Adapun alat-alat transportasi laut yang dominan digunakan adalah jujungkoh, lelepa, dan bodi.

\section{a) Jujungko}

Jujungko adalah sampan yang berukuran panjang sekitar 3 meter dengan muatan 2 orang. Alat ini digunakan oleh sebagian warga untuk mencari kenda 'cumi' atau digunakan sebagai pengantar apabila akan ke bodi 'perahu' yang diparkir di tengah laut.

\section{b) Lelepa}

Lelepa adalah sampan yang berukuran panjang sekitar 5-7 meter dengan kapasitas 1 ton atau dengan kapasitas 3-4 orang. Jenis alat ini digunakan untuk menangkap ikan simbula 'sarden', ciro 'lemuru', lure 'teri'. Khususnya digunakan di laut dengan memakai alat penangkapan yang berupa jareh 'jaring'. Dengan kata lain, alat ini biasanya digunakan khusus untuk kegiatan ngoncor.

c) Bodi

Bodi adalah jenis alat transportasi yang berukuran perahu kecil dengan panjang sekitar 20 meter dan lebar 5 meter dengan kapasitas muatan 6-7 ton. Jenis alat ini digunakan warga untuk menyelam atau menjaring ikan dengan menggunakan alat yang bernama serret 'mini porsen'. Baik dalam kegiatan menyelam maupun menjaring dengan serret dibutuhkan sebanyak 10 sampai 12 orang. Dalam melakukan aktivitas penyelaman dengan menggunakan alat transportasi berupa bodi itu sampai ke perairan Benua Australia dengan kurun waktu satu kali per tiga bulan atau dengan kedalaman air laut maksimal 30 meter. Sebaliknya, dalam kegiatan menjaring dengan menggunakan alat serret juga dengan menggunakan bodi dilakukan perjalanan sampai perbatasan timur Sumbawa dengan provinsi lain dengan kurun waktu juga satu kali dalam tiga bulan dengan kedalaman air laut yang 
dibutuhkan maksimal 30 meter. Ikan yang didapat oras 'oras', nonongkol 'tongkol', tutueh 'ikan terbang', timbaloah 'ikan todak' yang dilakukan oleh anak muda karena berpengaruh pada tenaga.

Dari beberapa jenis alat tersebut, yang membutuhkan tenaga yang banyak dalam penggunaannya adalah bodi. Hal ini disebabkan aktivitas baik menyelam maupun menjaring dengan menggunakan alat serret paling banyak membutuhkan tenaga, yaitu masing-masing berkisar 10 sampai 14 orang dalam setiap bodi 'perahu'-nya. Jumlah bido di Pulau Bungin untuk kedua jenis kegiatan melaut itu sekitar 50 bodi. Apabila dirata-ratakan maka akan menyerap sekitar 600-an jumlah orang yang berperan di dalamnya. Juragan 'pemilik perahu' tidak termasuk di dalamnya. Adapun pendapatan bagi setiap pelakunya dirata-ratakan sekitar 35 juta dengan 1 kompresor 'alat penyelaman'. Sebaliknya, apabila 2 kompresor yang dimiliki setiap bodi biasanya mendapatkan bagian penghasilan sebanyak 5-10 juta per anak buah kapal. Dapat dilihat bahwa dengan kedua jenis kegiatan tadi sudah dapat menyerap lebih banyak lagi sumber daya manusianya. Hanya yang masih diperdebatkan oleh mereka adalah kekurangan bodi dan serret bagi warganya. Di samping itu, sistem pengorganisasiannya masih dikelola secara tradisional.

Penyelaman dan pe-nyerret-an di lakukan di wilayah lain oleh karena di wilayahnya sudah mengalami kekurangan jenis fauna laut. Hal ini sebagai akibat cara mengeksploitasi sumberdaya laut di sekitar wilayahnya mengabaikan aspek pelestarian sumberdaya tersebut. Hal ini disebabkan pengetahuan tentang efek negatif dari cara mereka mengeksploitasi itu tidak ada. Untuk itu perlu pemahaman bagi mereka tentang bagaimana cara pemeliharaan yang baik bagi lingkungan lautnya.

\section{3) Sistem Pemasaran}

Dalam pemasaran hasil tangkapan di laut sebagian besar dikelola sendiri. Yang berperan dalam hal ini adalah kaum perempuan, khususnya untuk berbagai jenis ikan yang ditangkap dalam kegiatan ngoncor. Kaum perempuan itu ada yang berasal dari keluarga sendiri (istri sipengoncor) ada juga dari keluarga yang lain dengan mengambil dari keluarga yang melaut tersebut. Hal ini dilakukan setiap hari sesudah suami kembali ke Pulau Bungin. Hasil laut itu dibawa ke pasarpasar kecamatan bahkan sebagian besar dijual di pasar-pasar kabupaten. Di samping menjual hasil tangkapan laut, pihak perempuan Bajo Bungin juga membuat makanan sehari-hari untuk dijual kepada sesamanya (samma), seperti makanan surabe 'serabi' yang terbuat dari beras halus dan santan kelapa dengan harga Rp 500,- per buah, cucur yang terbuat dari beras ketan dengan gula merah atau putih kemudian digoreng yang dihargakan dengan Rp 500,-, rok parai рunu yang terbuat dari ketan dan kelapa gula merah di dalamnya yang dibungkus dengan daun pisang yang dihargakan dengan Rp 500,- per buah, dan makanan totoli yang dibuat dari campuran ketan dan gula merah yang dihargakan Rp 500,-. Dalam penjualan makanan ini biasanya yang berperan aktif adalah perempuan muda. Bagi yang sudah tidak punya suami atau janda-janda tua biasanya hanya mencari koah 'kerang' di pinggir laut. Kegiatan ini biasanya menghasilkan 15 kilogram dalan satu kali pencarian dalam sehari.

Sebaliknya, untuk pemasaran hasil tangkapan ikan melalui kegiatan matuhung 'menyelam', seperti kalora 'lobster', mutiara; kegiatan ngaramba, seperti ikan kiapu tikus, lambed dan sebagainya; kegiatan njareh dengan serret itu dijual sendiri oleh pihak awak bodi di pelelangan. Hal ini dilakukan oleh pihak laki-laki karena tempat pelelangan tidak terdapat di wilayah pemukimannya, namun di wilayah pencarian hasil tangkapan jenis fauna yang disebutkan tersebut, seperti di Sulawesi, NTT, Bali, bahkan di Jawa. 


\section{a) Kesenian Tradisional}

Pada masyarakat Bajo di Pulau Bungin Sumbawa juga terdapat bentukbentuk kesenian tradisional yang diwariskan dari generasi ke generasi. Bentuk kesenian yang dimaksud adalah kesenian gandah bajo, gambus, joge betote, joge bungin, kuringtigi, dan puju. Gandah bajo menggunakan 2 gandah 'gendang', 1 gong, dan 1 seruling. Gandah ini dimainkan pada saat dilakukan acaraacara adat di antaranya upacara tibaraki, bonteh 'pernikahan', dan sunna 'khitanan'. Iringan gambus yang dibarengi dengan balas pantun yang dilakukan oleh warganya apabila pada saat ada bonteh 'pernikahan'. Joge betote adalah bentuk kesenian yang berupa acara tarian antara laki-laki dengan perempuan yang diiringi dengan musik gendang yang digunakan pada upacara tibaraki. Kesenian ini dimulai dengan tarian yang dilakukan oleh pihak perempuan yang kemudian selendang yang digunakan dilemparkan kepada lelaki yang disenangi. Bagi lelaki yang terkena sabetan selendang itulah yang akan menjadi teman dalam menarinya.

Joge bungin adalah bentuk tarian yang diperankan oleh 2-4 orang perempuan dengan gaya lemah gemulai seiring tiupan angin laut. Wujud gerak dari tarian ini seperti orang tidur berdiri yang diiringi oleh manca 'pencat silat' yang diperankan oleh pihak laki-laki. Karuntigi adalah jenis kesenian dengan memukul rebana besar. Kesenian ini dilakukan pada saat ada perayaan warga. Hal ini diperankan oleh laki-laki yang berjumlah 5 orang yang diiringi dengan lagu-lagu religi Islam atau kegiatan barasanji 'bacaan pujian-pujian'. Kesenian puju juga berupa tarian yang dilakukan pada saat pesta bonteh 'perkawinan'. Kesenian ini diperankan oleh 3 orang pria yang diiringi dengan gendang, gong, dan seruling yang diperankan oleh 2 sampai 4 orang.

\section{b) Pengobatan Tradisional}

Dalam dunia orang Bajo di Pulau Bungin juga dikenal sistem pengobatan tradisional yang masih dipertahankan oleh generasi sekarang. Adapun jenis-jenis pengobatan tradisional mereka adalah:

\section{(1) Tibaraki}

Secara harafiah, tibaraki berarti menghanyutkan rakit, merupakan ritual adat yang masih dipegang teguh oleh masyarakat Bajo di Pulau Bungin. Tibaraki merupakan persembahan pada para leluhur yang wajib dilakukan oleh warga masyarakat yang memiliki hajat tertentu ataupun keinginan tertentu, termasuk di dalamnya apabila ada warga masyarakat yang mengalami sakit yang cukup berat.

Pengobatan tibaraki ini untuk mengobati penyakit yang akut atau tidak bisa disembuhkan dengan cara medis. Cara pengobatannya dengan bambu yang dibuat berbentuk segi empat yang di dalamnya terdapat bahan-bahan persembahan, seperti pisah 'pisang', antelo 'telur', manu ditape 'ayam bakar', songkol 'tumpeng' yang berwarna merah, kuning, putih, hitam, tebu, pinah 'siri', buas 'beras' yang berwarna merah, kuning, putih, hitam, bente 'jagung goreng kering'. Tibaraki ini ditujukan kepada penghuni laut yang bernama limbangah. Pengobatan dengan upacara tibaraki ini dilakukan oleh semua warga masyarakat yang disertai dengan pemukulan gendang oleh 2 orang, gong 1 orang, dan pipiu 'suling' oleh 1 orang dan khususnya diperankan oleh laki-laki. Wilayah upacaranya adalah di muara Bungin, tepatnya pada pertemuan arus.

\section{(2) Cubannah}

Cubannah adalah jenis pengobatan tradisional untuk mengobati anak yang sakit, demam, lemah lesu, kuning, tidak mau makan, dan penyakit dalam yang lain, bahkan untuk memperlancar proses kehamilan bagi ibu hamil. Cubannah terdiri dari dua jenis, yaitu cubannah madia payu, pengobatannya dilakukan di bawah payung yang ukurannya kecil yang 
kemudian dipasang di tempat tidur orang yang sakit dan cubannah madia lammeh, pengobatannya di dalam lammeh 'kelambu' tempat tidur yang pada bagian pinggir luarnya dikelilingi dengan makanan cucur dan ranggina, dan makanan lainnya. Sebaliknya, makanan yang ada di dalam adalah pisang susu, tebu, telur, dan lilin. Pengobatan cubannah ini dilakukan apabila yang sakit bukan keturunan asli orang Bajo.

\section{(3) Tiba pisah}

Tiba pisah juga hampir sama dengan sistem pengobatan cubannah. Hanya yang membedakan adalah wujud pisangnya berupa pisang kepok. Sebaliknya, bahanbahan dan cara-caranya sama dengan sistem pengobatan cubannah. Adanya pengobatan ini hanya dilakukan apabila yang sakit adalah orang keturunan asli Bajo.

\section{PENUTUP}

Simpulan yang dapat dikemukakan menyangkut penelitian"Potensi Budaya Masyarakat Bajo di Pulau Bungin Kabupaten Sumbawa" adalah sebagai berikut:

1. Potensi budaya masyarakat Bajo yang dapat teridentifikasi dalam penelitian ini meliputi sistem mata pencaharian tradisional, kesenian tradisional, dan pengobatan tradsional.

2. Sistem mata pencaharian tradisional meliputi alat-alat penangkapan ikan dan alat-alat tranportasi laut. Alat penangkapan ikan terdiri dari messi, njareh, matuhung, dan keramba, sedangkan alat transportasi laut terdiri dari jujungko, lelepa, dan bodi. Kesenian tradisional terdiri dari gandah bajo, gambus, joge betote, joge bungin, kuring tigi, dan puju. Pengobatan tradisional terdiri dari tibaraki, cubannah dan tiba pisah.

3.Berbagai potensi budaya seperti tersebut di atas, dapat dikembangkan menjadi kekuatan untuk kemajuan sosial ekonomi masyarakat Bajo di Pulau Bungin.

4. Pengembangan budaya masyarakat Bajo di Kabupaten Sumbawa memerlukan perhatian dan dukungan dari berbagai pemangku kepentingan.

5.Deskripisi mengenai potensi budaya masyarakat Bajo Pulau Bungin ini diharapkan dapat menjadi gambaran awal untuk pengembangan potensi kebudayaan Bajo lebih lanjut.

Saran yang dapat dikemukakan untuk pengembangan potensi budaya masyarakat Bajo di Pulau Bungin Kabupaten Sumbawa adalah sebagai berikut:

\section{Pelestarian budaya masyarakat Bajo} sebaiknya melibatkan berbagai pemangku kepentingan, baik swasta maupun pemerintah.

2.Pemerintah, baik pusat dan daerah hendaknya dapat membuat program dan kegiatan untuk meningkatkan potensi budaya masyarakat Bajo, sehingga kebudayaan yang ada di masyarakat tetap dapat dilestarikan.

3.Pelestarian yang menyangkut perlindungan, pengembangan, dan pemanfatan potensi budaya dapat dilakukan untuk meningkatkan derajat sosial ekonomi masyarakat Bajo.

4.Budaya masyarakat Bajo dapat diinternalisasikan kepada generasi muda Bajo melalui pelajaran muatan lokal sebagai usaha untuk memperkuat ketahanan budaya.

\section{DAFTAR SUMBER}

Ahimsa-Putra, Heddy Shri. 2001. Strukturalisme Levi-Strauss: Mitos dan Karya Sastra. Yogyakarta: Galang Press.

Danandjaja, James. 1980.

Foklor Indonesia: Ilmu Gosip, Dongeng, dan Lain-lain. Jakarta: PT Temprint. 
Endraswara, Suwardi. 2003.

Metodologi Penelitian Kebudayaan.

Yogyakarta: Gadjah Mada University

Press.

Syarifuddin. 2002.

Afiksasi Verba Bahasa Bajo di

Sumbawa. Tesis S2. Surakarta: Program

Pascasarjana Universitas Sebelas Maret.

2008.

Mantra Nelayan Bajo di Sumbawa:

Sebuah Kajian Makna (Isi). Humaniora

IV: 115-119.

2010 .

Kemetaforaan dalam Mantra Bajo di

Sumbawa; Pengungkap Sistem

Pengetahuan Lokal dan Global

Masyarakatnya. Disajikan dalam

Kongres Internasional Hari Bahasa Ibu

di Bandung Tanggal 19-20 Februari 2010.

Tim Penyusun Kamus. 2003.

Kamus Besar Bahasa Indonesia. Jakarta: Balai Pustaka. 
